\author{
A. CELMS ${ }^{1}$, I. TREVOHO ${ }^{2}$, V. PUKITE ${ }^{1}$, A. RATKEVICS ${ }^{1}$, V. CINTINA ${ }^{1}$ \\ ${ }^{1}$ Latvia University of Life Sciences and Technologies, armands.celms@llu.Iv \\ ${ }^{2}$ Department of Geodesy, Ihor Trevoho, Lviv Polytechnic National University, 12, S. Bandery str., Lviv, Ukraine, 79013
}

\title{
JUSTIFICATION OF THE HEIGHT MODELS AVAILABLE IN LATVIA
}

After improvement of geodetic networks in the territory of Latvia, situation is arisen that heights of geodetic points have changed. Therefore authors study in the research, what regularities form between the Baltic normal height system of year 1977 (BHS-77) and Latvian Normal Height System LHS-2000,5 height systems in the given points, as well as what inaccuracies can be observed, if ADTI map sheets are transformed by use of the determined methodology of recalculation of heights. Aim of the work is to research and analyse measurement data available in reports of improvement of local geodetic network of Ventspils, Jelgava, and Kuldoga and to compare values of heights of geodetic points with historical values of heights, as well as to give valuation about alignment of height systems. For the achievement of the aim following tasks are set: to analyse measurements available in the reports of local geodetic networks; to evaluate height differences between points in BHS-77 and LHS-2000,5 height systems; to give proposals in relation to compatibility of BHS-77 un LHS-2000,5 height systems. After valuation of data, we can draw conclusion that mutual compatibility of quasigeoid models LV'98 and LV'14 in all areas of measurement is regarded as appropriate. The historical heights of points of the local geodetic networks in comparison to improved levelled heights of BAS-77 are regarded as rather appropriate in local geodetic networks of Jelgava and Kuldoga; however, in local geodetic network of Ventspils, they are regarded as inappropriate.

Key words: quasigeoid model, normal height system, LHS-2000,5, BHS 1977

\section{Introduction}

After improvement of local geodetic networks in the territory of Latvia, the situation has arisen that heights of geodetic points have changed. Therefore authors study in research, what regularities form between the Baltic normal height system of year 1977 (BHS-77) and Latvian Normal Height System LHS-2000,5 height systems in the given points, as well as what inaccuracies can be observed, if ADTI map sheets are transformed by use of the determined methodology of recalculation of heights. Aim of the work is to research and analyse measurement data available in reports of improvement of local geodetic network of Ventspils, Jelgava, Kuldoga and to compare values of heights of geodetic points with historical values of heights, as well as to give valuation about alignment of height systems. For the achievement of the aim following tasks are set: to analyse measurements available in the reports of local geodetic networks; to evaluate height differences between points in BHS-77 and LHS-2000,5 height systems; to give proposals in relation to compatibility of BHS-77 un LHS-2000,5 height systems.

\section{Materials and Methods}

State geodetic network is formed by aggregate of many geodetic points, for which at least one type of characteristic is determined: height, gravimetric value of the Earth, value of geomagnetic field of Earth or coordinates. State geodetic network is formed by aggregate of points fixed in the field, which are located in the entire territory of the state. Such practice is necessary in order to give possibility to carry out, as well as use practically reference system of geodetic networks. Reference system of geodetic networks is theoretic, technologic and administrative base that provides realization of geodetic works [1].

Global positioning or horizontal network includes network of class G0, class G1 and class G2. G0 points located in the territory of Latvia are linked with ETRS89 reference system adopted in European Union. Eurasian continental movements have not impact on coordinates and maps based on base of system ETRS89 (see Fig. 1).

Levelling or vertical network includes levelling network of classes N1 and N2. In the territory of Latvia, 1870 points of class $\mathrm{N} 1$ are located, out of which 2 points are not found, 1 point is damaged, 4, probable, are destroyed and 88 are destroyed. In the territory of Latvia, 606 points of class N2 are located, out of which 3 points are not found and 6 points are destroyed [2]. After the change of height system in 1 December, 2014, for all points included in the state levelling network heights were recalculated from BHS-77 to LHS-2000,5. In the database of State Geodetic Network maintained by LGIA, it is possible to see heights of geodetic points in height system LHS-2000,5.

Gravimetric network includes points of network of class Gr1 and class Gr2. Function of the gravimetric network is to provide linkage of territory of Latvia with International Gravity Standardization Network IGSN71. The gravimetric network is based on three absolute points of gravimetric network of class 1 - Rīga Clock Silo, Pope 
and Višķi. The gravimetric network is based also on 48 points of class 2 of the gravimetric network, out of which 1 point is destroyed [2]. Gravimetric points provide an opportunity to carry out gravimetric measurements, which are necessary for the modelling of geoid models.

Latvian geomagnetic network provides linkage of territory of Latvia with International Geomagnetic Reference Field - IGRF-11. For calculations of the global geomagnetic model, also data from geomagnetic field of Latvia are used. The geomagnetic network of Latvia includes 7 points of network of class $\mathrm{Mg} 1$, out of which 1 is destroyed [3].
GNSS base station system LatPos includes 25 base stations. Base stations can be called also GNSS receiver. LatPos base stations provides its operation all year long without interruption. Their function is to accrue data received from satellites and further distribute data for all users of network LatPos. Base stations of LatPos gives opportunity to users to determine coordinates by GNNS receivers in real time with accuracy to two centimetres, and by use of post-processing of measurement data determine coordinates with accuracy to five millimetres. When some scientific project is elaborated, it is possible to use data accrued by base stations for longer period [4].

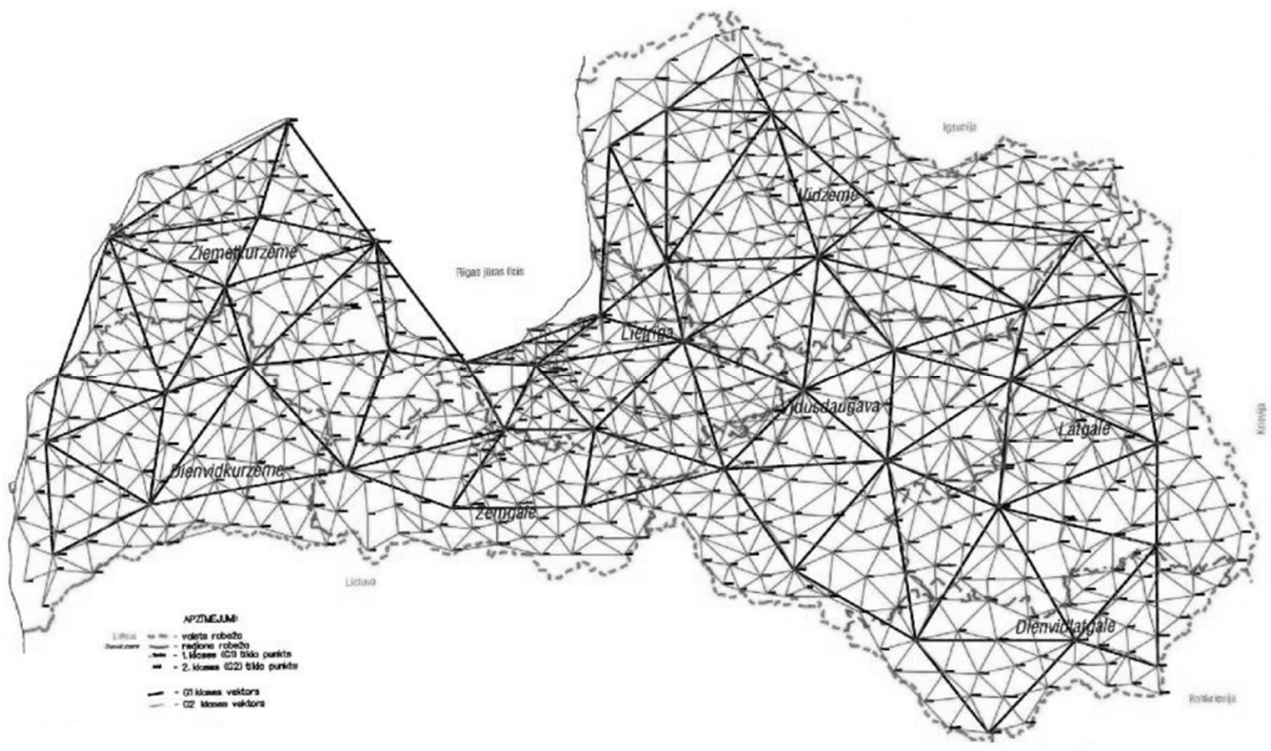

Fig. 1. Global positioning network [2]

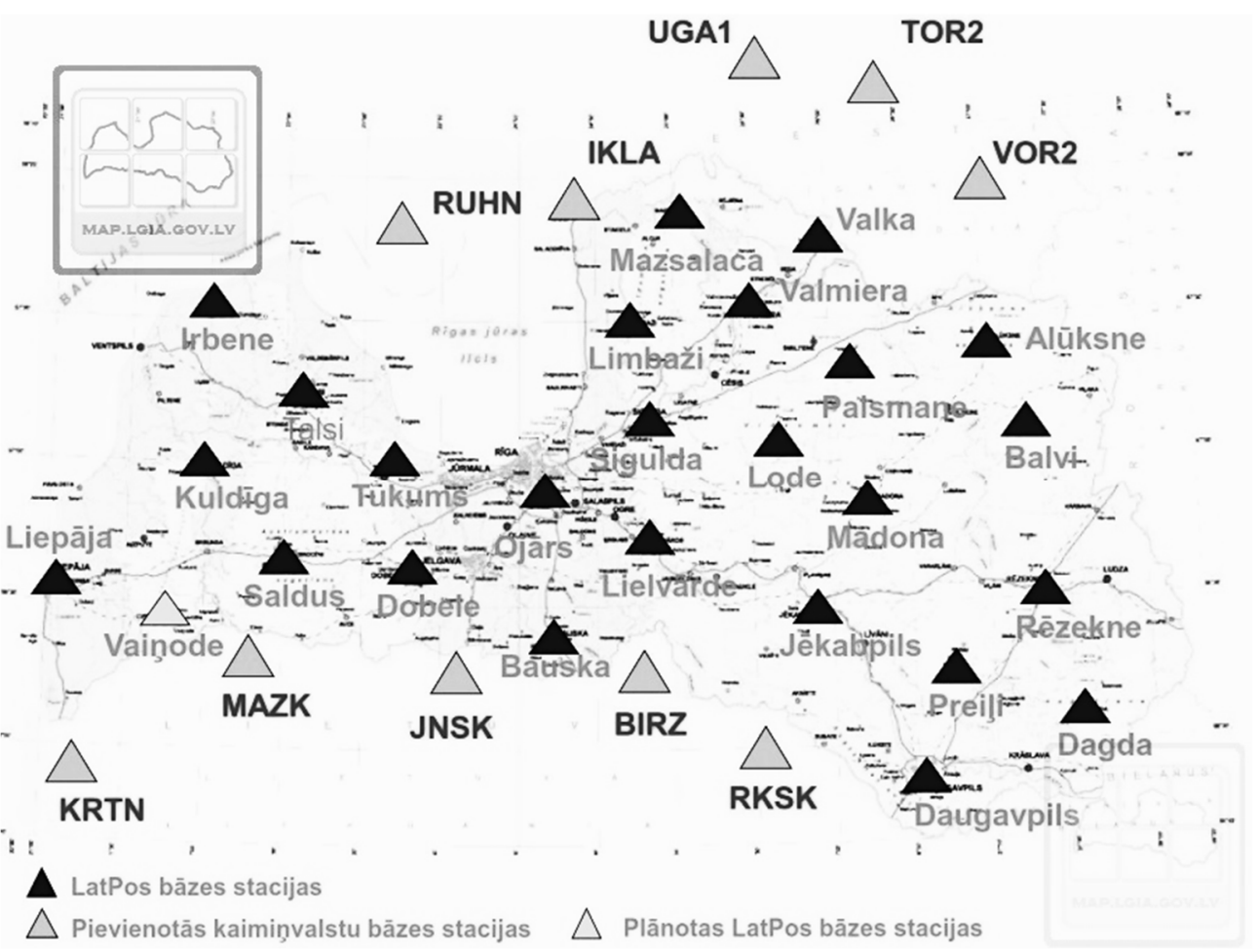

Fig. 2. Position of LatPos base stations [4] 
Each local geodetic network in the territory of Latvia is included in the geodetic network of the geodetic reference system of Latvia. Local geodetic network includes spatial points of GNSS (points of class G3), triangulation points (T2, T3, T4), polygonometry points (P1, P2, P3, P4), and marks and benchmarks of levelling network of class N3 and N4 [1].

In the territory of Latvia, Baltic system of normal heights of 1977 was used already since its creation. Linkage of territory of Latvia with Kronstadt datum is provided by levelling network of class 1 of Soviet Union. However, since December 1, 2014, in the territory of Latvia instead of height system BHS-77 height system LHS-2000,5 is realized. Kronstadt is one of the oldest water level regulation points in the world, in which the normal level of water in the Baltic Sea is measured. Kronstadt polder is almost so old as St. Petersburg. In 1977, the Baltic Height System was adopted in the entire territory of USSR and its datum was located in Kronstadt. From this place, the heights of all geodetic points were determined, after which the whole territory of USSR was measured and then mapped [5].

Model of quasigeoid LV'98 was created by Dr. Jānis Kaminskis by use of gravimetric measurement data depicted in maps of USSR times and method used in software elaborated in Denmark. It was a very significant achievement for Latvian geodesy, because it was the first official model of Latvian quasigeoid. At present, accuracy of Latvian quasigeoid model LV'98 reaches 6-8 centimetres [6].

In the territory of Latvia, since December 1, 2014, in the obtaining, preparation and maintenance of basic data of geospatial information, the Baltic system of normal heights of 1977 was replaced with Latvian system of normal heights in epoch 2000,5, which was realized on base of European Vertical Reference System (EVRS) [7]. Datum of EVRS and LHS-2000,5 height system is located in Amsterdam, Netherlands and is called "Amsterdam level". In the territory of Latvia, transition from BHS-77 to LHS-2000,5 was necessary, because since 1977 , vertical movements of earth's crust have caused discrepancy of $35 \mathrm{~mm}$, as well as factual differences of heights with data of levelling catalogues were greater than $5 \mathrm{~cm}$. Transition to LHS-2000,5 provided inclusion in European common height system [8].

European Vertical Reference System is related to gravity that provides opportunity to carry out transformation of measurement data between diverse height systems, as well as provides transition to other reference epochs. Aim of EVRS is to provide creation of unified height system for the whole Europe with accuracy of $1 \mathrm{~cm}$ [9].

When transition was carried out from Baltic normal height system of 1977 to Latvian normal height system, differences of heights in the territory of Latvia are approximately from $+12 \mathrm{~cm}$ in south-east of Latvia up to $+17 \mathrm{~cm}$ in north-west of Latvia [10].

With moment of creation of new height system LHS-2000,5 it was necessary to create also new model of quasigeoid - LV'14, which could be used for obtaining of measurement data by GNSS devices. Quasigeoid model $\mathrm{LV}^{\prime} 14$ is used as surface of transition of heights from ellipsoidal heights to LHS-2000,5 used in the Latvian state. Main aim of the quasigeoid model is to create best possible linkage with State Levelling Network.

In the elaboration of the research, measurement data, which are obtained in the improvement of local geodetic networks, are used. Measurement data consist of measurements of GNSS devices and measurement of levelling traverses. In the study, levelling data in BHS-77 and LHS-2000,5 height systems, as well as data of GNNS devices according to quasigeoid models LV'98 and LV'14 are used. In addition to these data, historical heights in height system BHS-77 are used for those geodetic points, for which such heights are available.

In order to have possibility to evaluate compatibility of height systems BHS-77 and LHS-2000,5, as well as of quasigeoids LV'98 and LV'14, geodetic points, for which measurements are made by both levelling and GNSS methods, are considered.

\section{Results and Discussion}

Compatibility of height systems in Jelgava City.

In Jelgava City, two compilations of measurement data on "PBrlielupe" and "Southern" parts were used. Points of "PBrlielupe" part of local geodetic network of Jelgava were measured before December 1, 2014; therefore, all measurement data were in BHS-77. Measurements of heights by GNSS devices were equalized repeatedly by the new quasigeoid model LV' 14 . In order to obtain the levelled heights in LHS-2000,5, functionality of recalculation of heights of points in the map browser of LGIA was used. It is possible to recalculate heights of points to LHS-2000,5 by giving coordinates of point in coordinate system LKS-92TM and by giving the height of point in BHS-77.

Data analysis was started by calculating deltas of height between heights of BHS-77 and heights, which are determined by GNSS device according to quasigeoid model LV'98. For the calculated deltas, the minimal $(2.9 \mathrm{~cm})$ and maximal $(17.8 \mathrm{~cm})$ value were determined. They were not taken into account, when the mean delta value was calculated. The mean delta value between the levelled BAS77 height and height, which is determined by GNSS device according to quasigeoid model LV'98, is $8.4 \mathrm{~cm}$. Accuracy of quasigeoid model LV'98 is estimated to $8 \mathrm{~cm}$. However, in this case, when the mean offset of measurements is calculated, deltas of differences of heights were used; therefore accuracy of quasigeoid should be estimated to $4 \mathrm{~cm}$. Accuracy of quasigeoid LV'98 for the part "PBrlielupe" of the local geodetic network of Jelgava City should be estimated as inappropriate.

In addition, mutual compatibility of quasigeoid models LV'98 and LV'14 was evaluated. For part "PBrlielupe" of the local geodetic network of Jelgava City difference of height between LHS-2000,5 and BHS-77 is determined $-15.3 \mathrm{~cm}$. Differences of heights between heights determined by GNSS devices according to 
quasigeoid models LV'14 and LV'98 were calculated. According to calculations of data, the mean difference of heights between quasigeoid models LV'98 and LV'14 is $20.9 \mathrm{~cm}$. Offset of height difference of quasigeoid models from determined $15.3 \mathrm{~cm}$ is $5.6 \mathrm{~cm}$, and maximal permitted offset of error of alignment of both quasigeoids is $6.25 \mathrm{~cm}$, consequently compatibility of quasigeoids in part "PBrlielupe" is considered as appropriate.

Points of "Southern" part of local geodetic network of Jelgava City were measured after December 1, 2014, therefore all measurement data were in LHS-2000,5, and however, after alignment of data, they were recalculated to BHS-77 in reverse order. Height measurements by GNSS devices were aligned repeatedly by the old quasigeoid model LV'98. Accuracy of the quasigeoid LV'98 for "Southern" part of the local geodetic network of Jelgava City is regarded as inappropriate (to $4 \mathrm{~cm}$ ). Accuracy of quasigeoid model LV'14 is estimated to $4.5 \mathrm{~cm}$. However, in this case, by calculation of mean measurement offset, deltas of differences of heights were used; therefore, accuracy of the quasigeoid is estimated to $2.25 \mathrm{~cm}$. Accuracy of quasigeoid LV'14 for the "Southern" part of the local geodetic network of Jelgava City is regarded as appropriate. The mean difference of heights between quasigeoid models LV'98 and LV'14 is $21.1 \mathrm{~cm}$; hence, compatibility of quasigeoids in the "Southern" part is regarded as appropriate.

If we compare parts "PBrlielupe" and "Southern" of the local geodetic network of Jelgava City, we can draw conclusion that "Southern" part before the improvement of the local geodetic network was measured more accurate than part "PBrlielupe". Also after the improvement, "Southern" part has better compatibility with quasigeoid models LV'98 and LV'14.

Compatibility of height systems in Ventspils City.

Points of the local geodetic network of Ventspils City were measured after December 1, 2014, therefore all measurement data were in LHS-2000,5, after alignment of data, they were recalculated to BHS-77 in reverse order. Height measurements by GNSS devices were aligned repeatedly by the old quasigeoid model LV'98.

Accuracy of quasigeoid model LV'98 is estimated to $8 \mathrm{~cm}$. However, in this case, in the calculation of mean measurement offset, deltas of differences of heights were used. Therefore accuracy of the quasigeoid is estimated to $4 \mathrm{~cm}$. Accuracy of quasigeoid LV'98 for the local geodetic network of Ventspils City is regarded as appropriate, but accuracy of quasigeoid LV'14 for the local geodetic network of Ventspils City is regarded as inappropriate (to $2.25 \mathrm{~cm}$ ). The mean difference of heights between quasigeoid models LV'98 and LV'14 is $22.7 \mathrm{~cm}$. Offset of the difference of heights of quasigeoid models from determined $17.2 \mathrm{~cm}$ is $5.5 \mathrm{~cm}$, and maximum permitted deviation of quasigeoid alignment error is $6.25 \mathrm{~cm}$, hence compatibility of quasigeoid for the local geodetic network of Ventspils City is regarded as appropriate.

Additionally, deltas of historical heights of BHS-77 with levelled BHS-77 height and height, which is determined by GNSS device according to quasigeoid model LV'98, were studied. For the calculated deltas, the minimum and maximum values were determined, which were not taken into account, when the mean value of deltas was calculated. The mean value of delta between the historical height in BHS-77 and the levelled height of BHS-77 is $8.2 \mathrm{~cm}$. However, the mean value of delta between the historical height in BHS-77 and height, which is determined by GNSS device according to quasigeoid model LV'98, is $10.2 \mathrm{~cm}$. If we evaluate these mean deltas, we can draw conclusion that the heights of points of geodetic network determined before and heights, which are determined by quasigeoid model LV'98 do not correspond to levelled heights of points in BHS-77.

Compatibility of height systems in Kuldoga City.

Points of the local geodetic network of Kuldoga City as in Ventspils City were measured after December 1, 2014; therefore, all measurement data were in LHS2000,5 , after alignment of data they were recalculated to BHS-77 in reverse order. Height measurements by GNSS devices were aligned repeatedly by the old quasigeoid model LV'98.

Accuracy of quasigeoid model LV'98 is estimated to $8 \mathrm{~cm}$. However, in this case, by calculation of mean measurement offset, deltas of differences of heights were used, and therefore accuracy of the quasigeoid is estimated to $4 \mathrm{~cm}$. Accuracy of quasigeoid LV'98 for the local geodetic network of Kuldoga City is regarded as appropriate, but accuracy of quasigeoid model LV'14 is estimated to $4.5 \mathrm{~cm}$. However, in this case, in the calculation of mean measurement offset, deltas of differences of heights were used, and therefore accuracy of the quasigeoid is estimated to $2.25 \mathrm{~cm}$. Accuracy of quasigeoid LV'14 for the local geodetic network of Kuldoga City is regarded as inappropriate. However, mutual compatibility of quasigeoids for the local geodetic network of Kuldoga City is regarded as appropriate.

The mean value of delta between the historical height of BHS-77 and the levelled height of BHS-77 is $2.4 \mathrm{~cm}$. However, the mean value of delta between the historical height of BHS-77 and the height, which is determined by GNSS device according to quasigeoid model LV'98, is $1.7 \mathrm{~cm}$ (see Annex 4). When we evaluate these mean deltas, we can draw conclusion that the heights of points of geodetic network determined before and heights, which are determined by quasigeoid model LV'98, are rather corresponding to levelled heights of points in BHS-77.

Summary of results obtained in the analysis of measurement data is compiled on the base of measurement data on the local geodetic networks of Jelgava, Ventspils and Kuldoga.

Accuracy of quasigeoid model LV'98 is regarded as appropriate in Ventspils and Kuldoga; however, in Jelgava, this accuracy is much worse than determined for this quasigeoid model. If the mean accuracy of quasigeoid LV'98 is calculated for four areas used in master's theses, it is $10.8 \mathrm{~cm}$. The accuracy of quasigeoid LV'14 is regarded as appropriate for the "Southern" part of the 
local geodetic network of Jelgava, however for local geodetic network of Ventspils, Kuldoga and "PBrlielupe" part of local geodetic network of Jelgava this accuracy is regarded as inappropriate. The calculated mean accuracy of quasigeoid LV'14 according to four areas used in master's theses is $6.4 \mathrm{~cm}$. Mutual compatibility of quasigeoid models LV'98 and LV'14 in all measurement areas is regarded as appropriate.

The historical heights of points of local geodetic networks in comparison to improved levelled heights of BHS-77 are regarded as rather appropriate in networks of Jelgava and Kuldoga. Nevertheless, for the local geodetic network of Ventspils these heights are regarded as inappropriate. The historical heights of points of local geodetic networks in comparison to heights of points, which are obtained according to quasigeoid model LV'98, are regarded as inappropriate in Ventspils City and Jelgava City. In Kuldoga City, they are regarded as appropriate.

In ADTI (Topographic Information of High Degree of Details) map sheets, height measurement data, which are measured by all methods mentioned above, are saved. From obtained results of analysis of measurement data, we can draw conclusion that Kuldoga City is the only area, where information of ADTI map sheets can be used in full; although accuracy of quasigeoid model LV'14 is not appropriate to defined indices of accuracy, offset of its accuracy is relatively small. But in areas of Ventspils and Jelgava, information of ADTI map sheets on heights would not be desirable to use by preparing projects or carrying out some researches, because it is not known, in which places measurements are made from points of local geodetic network and where from reference points installed by GNSS devices.

\section{Conclusions}

1. In Ventspils and Kuldoga, accuracy of quasigeoid model LV'98 against BHS-77 corresponds to determined accuracy of quasigeoid model LV'98. In Jelgava, accuracy of quasigeoid model LV'98 against BHS-77 does not correspond to determined accuracy of quasigeoid model LV'98.

2. In the "Southern" part of the local geodetic network of Jelgava, accuracy of quasigeoid model LV'14 against LHS-2000,5 corresponds to the determined accuracy of quasigeoid model LV'14. In Ventspils, Kuldoga and in "PBrlielupe" part of the local geodetic network of Jelgava, accuracy of quasigeoid model LV'14 against LHS-2000,5 does not correspond to the determined accuracy of quasigeoid model.

3. Mutual compatibility of quasigeoid models LV'98 and LV'14 in all areas of measurements is regarded as appropriate.

4. Historical heights of points of local geodetic networks in comparison to the improved levelled heights in BHS-77 are regarded as rather appropriate in local geodetic networks of Jelgava and Kuldoga; however, they are regarded as inappropriate for the local geodetic network of Ventspils.
5. In Kuldoga City, information of ADTI map sheets can be used in full. In Jelgava and Ventspils, when projects are prepared or some researches are conducted, it is not desirable to use information on heights of ADTI map sheets.

6. It is necessary to improve quasigeoid model LV'14, so that it corresponds to defined indices of accuracy.

7. The existing ADTI map sheets should be complemented with new accurate measurements, so that overall picture on topographic situation is create without taking into account heights.

\section{Acknowledgements}

We are grateful to the company GEODĒZISTS Ltd and land surveyor Janis Ondrups for the selection of data used for this study.

\section{References}

Auziņš A., Reiniks M. (2014). Metodiskie norādījumi "Apvidus topogrāfiskā uzmērīšana". viewed 27.04.2017., available at http://lmb.lv/wpcontent/uploads/2014/09/ATU_30092014.pdf (In Latvian).

Aleksejenko I. Valsts ǵeodēziskās politikas īstenošana. viewed 24.04.2017., available at map.lgia.gov.lv/file.php?id=275 (In Latvian).

Lieksne L. Valsts ǵeodēziskās politikas īstenošana. viewed 05.05.2018., available at http://www.lgia. gov.lv/Publikacijas/ /media/7BCCDBAB58C549A6 9B706E 9433C99855.ashx (In Latvian).

LatPos: LGIA homepage. viewed 20.05.2017., available at http://map.lgia.gov.lv/index.php?lang=0\&cPath=2\&t xt_id=13\# (In Latvian).

Богданов В. И. (2015). Кронштадтский футшток и его Шепелевский дублер. Санкт-Петербургский научный центр РАН. 248 lpp.

Janpaule I. (2014). Augstas precizitātes Latvijas ǵeōida model̦a noteikšanas metodes: promocijas darbs. viewed 15.03.2018., available at http://publikacijas. lu.lv/files/2015/01/pub18086.pdf (In Latvian).

Latvijas normālo augstumu sistēma: LGIA homepage. viewed 05.10.2017., available at http://www.lgia. gov.lv/Aktualitates/2014/12/01-1.aspx (In Latvian).

Bērzin̦š V. (2014). Aktualitātes ǵeotelpiskās informācijas attīstības koncepcijas realizācijā. viewed 19.07.2017., available at http://www.envirotech.lv/ _s/media/pdf/Aktualitates_\%20geokoncepcijas_real izacija-Valdis\%20Berzins.pdf (In Latvian).

Reiniks M., Kalinka M., Lazdāns J., Klīve J, Ratkus B. (2010). Valsts augstumu izejas līmeņa noteikšana. viewed 05.05.2018., available at https://ortus.rtu.lv/ science/lv/publications/8895/fulltext.

Kalinka M., Reiniks M., Aleksejenko I. Eiropas vertikālā atskaites sistēma Latvijā. viewed 07.04.2018., available at https://www.lu.lv/fileadmin/user_upload/ lu_portal/projekti/70konference/materiali/ Aleksejenko_EVAS_LV.pdf (In Latvian) 


\begin{abstract}
А. ЦЕЛМС ${ }^{1}$, I. ТРЕВОГО $^{2}$, В. ПУКІТЕ ${ }^{1}$, А. РАТКЕВИЧС ${ }^{1}$, В. ЦИНТІНА ${ }^{1}$
${ }^{1}$ Латвійський університет природничих та технологій, armands.celms@1lu.lv;

2 Національний університет “Львівська політехніка"
\end{abstract}

\title{
ОБГРУНТУВАННЯ ВИСОТНИХ МОДЕЛЕЙ, НАЯВНИХ У ЛАТВІЇ
}

Після вдосконалення геодезичних мереж на території Латвії склалася ситуація, що висота геодезичних точок змінилася. Тому автори в дослідженні вивчають, які закономірності формуються між балтійською системою нормальних висот 1977 року (BHS-77) та латвійською системою нормальної висоти LHS-2000,5, a також які неточності можна спостерігати, якщо аркуші карт ADTI перетворюються за допомогою визначеної методології перерахунку висот. Мета роботи - дослідити та проаналізувати дані вимірювань, наявні у звітах про вдосконалення локальної геодезичної мережі Вентспілса, Слгави і Кулдіги, та порівняти значення висот геодезичних точок з історичними значеннями висот, а також дати оцінку щодо вирівнювання висотних систем. Для досягнення мети поставлені наступні завдання: проаналізувати вимірювання, наявні у звітах локальних геодезичних мереж; оцінити різницю висот між точками в системах висоти BHS-77 та LHS-2000,5; надати пропозиції щодо сумісності систем висоти BHS-77 та LHS-2000,5. Після оцінки даних можна зробити висновок, що взаємна сумісність квазігеоїдних моделей LV'98 та LV'14 у всіх областях вимірювання є відповідною. Історичні висоти точок локальних геодезичних мереж порівняно 3 поліпшеними висотами висоти BAS-77 вважаються досить доречними в локальних геодезичних мережах Слгави та Кулдіги; однак у місцевій геодезичній мережі Вентспілса вони розглядаються як недоречні.

Ключові слова: квазігеоїдна модель, система нормальної висоти, LHS-2000,5, BHS 1977

\section{References}

Auziņš A., Reiniks M. (2014) Metodiskie norādījumi „Apvidus topogrāfiskā uzmērī̌̌ana”. viewed 27.04.2017., available at http://lmb.lv/wp-content/uploads/2014/09/ATU_30092014.pdf (In Latvian)

Aleksejenko I. Valsts ǵeodēziskās politikas īstenošana. viewed 24.04.2017., available at map.lgia.gov.lv/file.php?id=275 (In Latvian)

Lieksne L. Valsts ǵeodēziskās politikas īstenošana. viewed 05.05.2018., available at http://www.lgia.gov.lv/Publikacijas/ /media/7BCCDBAB58C549A69B706E 9433C99855.ashx (In Latvian)

LatPos: LGIA homepage. viewed 20.05.2017., available at http://map.lgia.gov.lv/index.php? lang=0\&cPath=2\&txt_id=13\# (In Latvian)

Bogdanov V. I. (2015) Kronshtadtskiy futshtok i ego Shepelevskiy dubler. Sankt-Peterburgskiy Nauchnyiy tsentr RAN.248 lpp.

Janpaule I. (2014) Augstas precizitātes Latvijas ǵeoīda modeḷa noteikšanas metodes: promocijas darbs. viewed 15.03.2018., available at http://publikacijas.lu.lv/files/2015/01/pub18086.pdf (In Latvian)

Latvijas normālo augstumu sistēma: LGIA homepage. viewed 05.10.2017., available at http://www.lgia.gov.lv/ Aktualitates/2014/12/01-1.aspx (In Latvian)

Bērziņš V. (2014) Aktualitātes ǵeotelpiskās informācijas attīstības koncepcijas realizācijā. viewed 19.07.2017., available at http://www.envirotech.lv/_s/media/pdf/Aktualitates_\%20geokoncepcijas_real izacija-Valdis\%20Berzins.pdf (In Latvian)

Reiniks M., Kaļinka M., Lazdāns J., Klīve J, Ratkus B. (2010) Valsts augstumu izejas līmeņa noteikšana. viewed 05.05.2018., available at https://ortus.rtu.lv/science/lv/publications/8895/fulltext

Kaļinka M., Reiniks M., Aleksejenko I. Eiropas vertikālā atskaites sistēma Latvijā. viewed 07.04.2018., available at https://www.lu.lv/fileadmin/user_upload/lu_portal/projekti/70konference/mat eriali/Aleksejenko_EVAS_LV.pdf Latvian) 